\title{
PENGARUH PEMBELAJARAN BERBASIS MASALAH TERHADAP KEMAMPUAN KOMUNIKASI MATEMATIS SISWA SMA
}

\author{
Mikrayanti* \\ Program Studi Pendidikan Matematika, STKIP Bima \\ *Email: kenisha.mikrayanti@gmail.com
}

\begin{abstract}
ABSTRAK
Penelitian ini bertujuan untuk memperoleh gambaran tentang pengaruh pembelajaran matematika dengan menggunakan pendekatan pembelajaran berbasis masalah terhadap kemampuan komunikasi matematis siswa kelas XI IPA pada salah satu SMA di kabupaten Bima. Penelitian ini merupakan penelitian quasi eksperimen dengan desain penelitian yang digunakan adalah Posttest Only Control Design. Populasi dalam penelitian ini adalah seluruh siswa SMA kelas XI IPA di salah satu SMAN Kabupaten Bima yang berjumlah 199 orang yang tersebar dalam 6 kelas IPA. Sampel yang digunakan dalam penelitian ini hanya mengambil dua kelas yaitu kelas eksperimen dan kelas kontrol, dengan tekhnik pengambilan sampel secara cluster random sampling. Instrumen yang digunakan dalam penelitian ini adalah instrumen tes dan non-tes. Adapun instrumen tes berupa tes berbentuk uraian untuk mengukur kemampuan komunikasi matematis siswa. Hasil penelitian menunjukkan bahwa model pembelajaran berbasis masalah berpengaruh terhadap kemampuan komunikasi matematis siswa kelas XI IPA pada salah satu SMAN di bima.
\end{abstract}

Kata kunci: pembelajaran berbasis masalah, kemampuan komunikasi matematis.

\begin{abstract}
This study aims to obtain an overview of the effect of learning mathematics using a problem-based learning approach on the mathematical communication skills of class XI science students at a school in Bima district. This research is a quasi-experimental research with the research design used is Posttest Only Control Design. The population in this study were all high school students of class XI science in one of the SMA Regency of Bima, totaling 199 people spread over 6 science classes. The sample used in this study only took two classes, namely the experimental class and the control class, with cluster random sampling technique sampling. The instruments used in this study were test and non-test instruments. The test instrument is in the form of a test in the form of a description to measure students' mathematical communication skills. The results showed that the problem-based learning model had an effect on the mathematical communication skills of class XI science students at one of the senior high schools in the bima district.
\end{abstract}

Keywords: problem based learning, mathematical communication ability.

\section{PENDAHULUAN}

Proses pembelajaran matematika merupakan salah satu bagian dari keseluruhan proses pendidikan di sekolah maupun di perguruan tinggi, yang diharapkan dengan proses ini tujuan pendidikan akan dapat dicapai antara lain dalam bentuk terjadinya perubahan sikap, keterampilan, serta meningkatnya kemampuan berpikir siswa. Hal ini senada dengan 
pernyataan Ebbutt dan Straker (dalam Suhitno, 2003:6) yang berpendapat bahwa matematika sekolah atau yang kemudian disebut sebagai matematika adalah kegiatan penelusuran pola dan hubungan, kreativitas yang memerlukan imajinasi, intuisi, dan penemuan, kegiatan problem solving dan kegiatan komunikasi. Dalam Kurikulum Tingkat Satuan Pendidikan, dinyatakan bahwa siswa harus memiliki seperangkat kompetensi yang diharapkan dapat tercapai dalam belajar matematika untuk Sekolah Menengah Atas yaitu: 1). Memahami konsep matematika, 2). Menggunakan penalaran, 3). Memecahkan masalah, 4). Mengkomunikasikan gagasan, 5) Memiliki sikap menghargai kegunaan matematika dalam kehidupan.

Berdasarkan standar kompetensi yang termuat dalam kurikulum tersebut, aspek komunikasi merupakan kemampuan yang harus dimiliki siswa sebagai standar yang harus dikembangkan. Pembelajaran matematika di sekolah harus dapat menyiapkan siswa untuk memiliki kemampuan komunikasi matematis sebagai bekal untuk menghadapi tantangan perkembangan dan perubahan.

Reys (Suherman dkk, 2003) mengatakan bahwa matematika merupakan suatu bahasa. Matematika sebagai suatu bahasa tentunya sangat diperlukan untuk dikomunikasikan baik secara lisan maupun tulisan sehingga informasi yang disampaikan dapat diketahui dan dipahami oleh orang lain. Seperti apa yang dikemukakan Cockroft (Shadiq, 2004: 19), 'We believe that all these perceptions of the usefulness of mathematics arise from the fact that mathematics provides a means of communication which is powerful, concise, and unambiguous.' Pernyataan ini menunjukkan tentang perlunya para siswa belajar matematika dengan alasan bahwa matematika merupakan alat komunikasi yang sangat kuat, teliti, dan tidak membingungkan. Sebagai contoh untuk notasi 20 x 4 dapat digunakan untuk menyatakan berbagai hal seperti: luas permukaan kolam dengan ukuran panjang 20 meter dan lebar 4 meter, banyaknya roda pada 20 buah mobil, atau jarak tempuh sepeda motor selama 4 jam dengan kecepatan $20 \mathrm{~km} / \mathrm{jam}$. Contoh ini telah menunjukkan bahwa suatu notasi, yaitu 20 x 4 dapat menyatakan suatu hal yang berbeda. Selain itu, lambang, gambar, dan tabel dapat juga digunakan untuk menyampaikan informasi. Bayangkan jika siswa tidak mempunyai kemampuan komunikasi dalam matematika, bagaimana mereka dapat menyatakan suatu notasi dengan makna yang berbeda? Tentu saja notasi 20 x 4 menjadi tidak bermakna.

Dalam proses belajar mengajar di sekolah, guru sering menemui hambatan dalam memberikan motivasi kepada siswa tentang pelajaran matematika karena siswa menganggap 
bahwa matematika merupakan mata pelajaran yang sulit untuk dipahami. Akibat dari anggapan tersebut muncul rasa tidak percaya diri siswa dalam belajar matematika ditambah lagi dengan gaya belajar guru yang membuat siswa menjadi takut untuk mengungkapkan pendapat. Akibatnya siswa tidak mampu menyelesaikan soal-soal yang berhubungan dengan komunikasi matematis.

Berdasarkan permasalahan tersebut, guru harus mengupayakan pembelajaran dengan menggunakan model-model belajar yang inovatif, yakni yang dapat memberikan peluang dan mendorong siswa untuk melatihkan kemampuan komunikasi matematis. Salah satu model pembelajaran yang dapat diterapkan dalam pembelajaran matematika adalah pembelajaran berbasis masalah. Pembelajaran Berbasis Masalah adalah suatu model pembelajaran yang dimulai dengan menyelesaikan suatu masalah, tetapi untuk menyelesaikan masalah itu siswa memerlukan pengetahuan baru untuk dapat menyelesaikannya.

Bay dalam Yurniwati (2009) menjelaskan pembelajaran berbasis masalah dalam matematika adalah mengajarkan pengetahuan dan keterampilan dalam bentuk pemecahan masalah. Masalah disajikan sebagai konteks dan stimulus untuk belajar. Menurut Rusman (Mutmainnah, Dusalan, \& Muchlis, 2018) mengemukakan bahwa siswa memahami konsep dan prinsip dari suatu materi dimulai dari belajar dan belajar terhadap situasi atau masalah yang diberikan melalui investigasi, inquiry, dan pemecahan masalah. Siswa membangun konsep atau prinsip dengan kemampuannya sendiri yang mengintegrasikan keterampilan dan pengetahuan yang sudah dipahami sebelumnya. Dari uraian tersebut, maka masalah yang dikaji dalam penelitian ini adalah pengaruh pembelajaran berbasis masalah terhadap kemampuan komunikasi matematis pada siswa SMA.

\section{METODE PENELITIAN}

Penelitian ini merupakan penelitian quasi eksperimen karena dalam desain ini peneliti tidak dapat mengontrol semua variabel dari luar yaitu faktor luar yang tidak diteliti dan menjadi pengganggu sehingga mempengaruhi jalannya eksperimen. Desain penelitian yang digunakan adalah Posttest Only Control Design (Sugiyono dalam Nursakirah, 2020). Populasi dalam penelitian ini adalah seluruh siswa SMA kelas XI IPA disalah satu SMAN Kabupaten Bima yang berjumlah 199 orang yang tersebar dalam 6 kelas IPA. Sampel yang digunakan dalam penelitian ini hanya mengambil dua kelas yaitu kelas eksperimen berjumlah 32 orang dan kelas kontrol berjumlah 35 orang yang masing-masing berada pada kelas XI IPA1 dan 
IPA3, dengan tekhnik pengambilan sampel secara cluster random sampling. Instrumen yang digunakan dalam penelitian ini adalah instrumen tes dan non-tes. Adapun instrumen tes berupa tes berbentuk uraian untuk mengukur kemampuan komunikasi matematis siswa.

\section{HASIL DAN PEMBAHASAN}

\section{Hasil Penelitian}

Data kemampuan komunikasi matematis siswa diperoleh melalui postes. Berikut ini merupakan data hasil analisis kemampuan komunikasi matematis pada kelas eksperimen dan kontrol yang disajikan pada berikut

Tabel 1: Skor Rata-rata Kemampuan Komunikasi Matematis

\begin{tabular}{ccccccccccc}
\hline Tes & \multicolumn{4}{c}{ Kelompok Eksperimen } & \multicolumn{5}{c}{ Kelompok Kontrol } \\
\cline { 2 - 12 } & $\mathrm{N}$ & $x_{\text {min }}$ & $x_{\text {maks }}$ & $\ldots \ldots \ldots$ & $S$ & $\mathrm{~N}$ & $x_{\min }$ & $x_{\text {maks }}$ & $\ldots \ldots \ldots$ & $s$ \\
\hline Postes & 32 & 10 & 16 & 12,94 & 1,544 & 35 & 9 & 14 & 11,26 & 1,268 \\
\hline
\end{tabular}

Berdasarkan Tabel 1 di atas, terlihat bahwa pencapaian skor rata-rata kemampuan komunikasi matematis pada kelas eksperimen 8,55\% lebih tinggi daripada kelas kontrol. Untuk membuktikan bahwa skor kemampuan komunikasi matematis siswa kelompok eksperimen dan kelompok kontrol berbeda atau tidak secara signifikan, maka dilakukan uji uji perbedaan rataan dengan menggunakan uji- $t$, menggunakan Compare Mean Independent Samples Test. Sebelum dilakukan uji perbedaan rataan, sebagai salah satu persyaratan dalam analisis kuantitatif adalah terpenuhinya asumsi kenormalan distribusi data yang akan dianalisis maka terlebih dahulu dilakukan uji normalitas dan uji homogenitas variansi. Adapun hipotesisnya yaitu:

$\mathrm{H}_{0}$ : Data berdistribusi normal

$\mathrm{H}_{\mathrm{a}}$ : Data tidak berdistribusi normal

Kriteria pengujian: Jika sig $>0,05$ maka Terima $\mathrm{H}_{0}$

Jika sig $\leq 0,05$ maka Tolak $\mathrm{H}_{0}$

Uji normalitas dihitung dengan menggunakan test of normality dari KolmogorovSmirnov dalam SPSS 16.0 for windows. Berikut adalah rangkuman uji normalitas skor kemampuan komunikasi matematis. 
Tabel 2: Uji Normalitas Skor Kemampuan Komunikasi Matematis

\begin{tabular}{ccccccc}
\hline Kelompok & \multirow{2}{*}{ Tes } & \multicolumn{2}{c}{ Kolmogorov-Smirnov } & Kesimpulan & Keterangan \\
\cline { 3 - 5 } & & Statistik & Df & Sig. & & \\
\hline Eksperimen & Postes & 0,141 & 32 & 0,105 & Terima $\mathrm{H}_{0}$ & Normal \\
Kontrol & & 0,182 & 32 & 0,005 & Tolak $\mathrm{H}_{0}$ & Tidak normal \\
\hline
\end{tabular}

Berdasarkan Tabel 2, diketahui bahwa hasil skor kemampuan komunikasi matematis siswa kelompok eksperimen memiliki nilai signifikan lebih besar dari $\alpha=0,05$, sehingga Ho diterima. Hal ini menunjukkan bahwa data skor kemampuan komunikasi kelompok eksperimen berdistribusi normal, sedangkan kemampuan komunikasi matematis siswa kelompok kontrol memiliki nilai signifikan lebih kecil dari $\alpha=0,05$, sehingga Ho ditolak yang artinya sebaran data kemampuan komunikasi matematis kelas kontrol tidak berdistribusi normal.

Jika ada salah satu atau kedua kelompok tidak berdistribusi normal maka uji perbedaan dilanjutkan dengan uji non-parametrik yaitu uji Mann-Whitney. Pasangan hipotesis yang akan diuji adalah sebagai berikut:

$\mathrm{H}_{\mathrm{O}}$ : Tidak terdapat perbedaan skor kemampuan komunikasi matematis antara kelas eksperimen dengan kelas kontrol.

$\mathrm{H}_{\mathrm{a}}$ : Terdapat perbedaan skor kemampuan komunikasi matematis antara kelas eksperimen dengan kelas kontrol.

Kriteria pengujian: Jika sig $>0,05$ maka Terima $\mathrm{H}_{0}$

Jika sig $\leq 0,05$ maka Tolak $\mathrm{H}_{0}$

Berikut adalah rangkuman uji perbedaan skor kemampuan komunikasi matematis.

Tabel 3: Hasil Uji Perbedaan Kemampuan Komunikasi Matematis

\begin{tabular}{|c|c|c|c|c|}
\hline \multirow{2}{*}{ Tes } & \multicolumn{2}{|c|}{ Mann-Whitney } & \multirow{2}{*}{ Kesimpulan } & Keterangan \\
\cline { 2 - 3 } & $\begin{array}{c}\text { Asymp.Sig. } \\
\text { (2-tailed) }\end{array}$ & $\mathrm{Z}$ & & Terdapat perbedaan \\
\hline Postes & 0,000 & $-4,193$ & Tolak $\mathrm{H}_{0}$ & Ter \\
\hline
\end{tabular}

Berdasarkan Tabel 3 di atas, diketahui bahwa hasil uji perbedaan rataan kemampuan komunikasi, nilai Asymp.Sig.(2-tailed) lebih kecil dari $\alpha=0,05$. Sehingga Ho ditolak, artinya terdapat perbedaan antara skor kemampuan komunikasi matematis siswa kelas eksperimen dan kelas kontrol. Dengan demikian dapat disimpulkan bahwa kemampuan akhir siswa untuk tes kemampuan komunikasi matematis, memang terdapat perbedaan. Artinya model pembelajaran 
berbasis masalah berpengaruh terhadap kemampuan komunikasi matematis siswa kelas XI IPA pada salah satu SMAN dikabupaten bima.

\section{Pembahasan}

Berdasarkan pada data yang telah dianalisis, menunjukkan bahwa pembelajaran berbasis masalah berpengaruh secara signifikan terhadap kemampuan komunikasi matematis siswa kelas ekperimen dengan kelas kontrol. Dimana rata-rata kemampuan komunikasi matematis siswa pada kelas eksperimen lebih tinggi dari pada rata-rata kemampuan komunikasi matematis siswa kelas kontrol. Hal ini menunjukan bahwa pembelajaran dengan pendekatan pembelajaran berbasis masalah memberi kontribusi yang lebih tinggi terhadap kemampuan komunikasi matematis siswa dibandingkan dengan pembelajaran konvensional.

Terjadinya peningkatan kemampuan komunikasi matematis melalui pembelajaran berbasis masalah disebabkan oleh adanya perbedaan mendasar yang terjadi selama proses pembelajaran pada kelompok siswa yang mendapat pembelajaran dengan pembelajaran berbasis masalah dan siswa yang mendapat pembelajaran konvensional. Perbedaan mendasar antara pembelajaran berbasis masalah dan konvensional terletak pada orientasi belajar. Pada pembelajaran konvensional siswa memperoleh pengetahuan tentang fakta, konsep dan prosedur seperti aturan dan rumus-rumus dari guru dan buku sumber. Kemudian pengetahuan tersebut digunakan untuk menjawab soal-soal bersifat mengulang dan aplikasi prosedur pada masalah rutin.

Sedangkan pada pembelajaran berbasis masalah yang terjadi adalah sebaliknya, pada awal pembelajaran siswa dihadapkan pada masalah yang berfungsi sebagai salah satu stimulus dan pemicu siswa untuk berpikir. Permasalahan pada proses pembelajaran berbasis masalah tidak dirancang untuk memberikan informasi yang sebanyak-banyaknya kepada siswa. Masalah yang disajikan lebih ditekankan untuk mengembangkan keterampilan siswa dalam mengenali masalah dan merancang strategi pemecahannya. Pada pembelajaran berbasis masalah siswa dihadapkan dengan berbagai masalah yang menantang yang dapat menghadirkan kegiatan berpikir siswa dalam menyelesaikan masalah-masalah matematika, melibatkan siswa melakukan proses doing math secara aktif, mengemukakan kembali ide matematika dalam membentuk pemahaman baru. Berarti masalah bertindak sebagai kendaraan proses belajar untuk mencapai tujuan. Konsep pembelajaran seperti itu, dapat memfasilitasi siswa melakukan eksporasi, investigasi dan pemecahan masalah. Seperti Sabandar (2005: 2) 
mengemukakan bahwa situasi pemecahan masalah merupakan suatu tahapan di mana ketika individu dihadapkan kepada suatu masalah ia tidak serta merta mampu menemukan solusinya, bahkan dalam proses penyelesaiannya ia masih mengalami kebuntuan. Pada saat itulah terjadi konflik kognitif yang tidak menutup kemungkinan memaksa siswa untuk berpikir.

Tidak seperti dalam pembelajaran konvesional, suasana kelas dalam pembelajaran berbasis masalah bersifat dinamis. Siswa dikondisikan dan terlihat sibuk berdiskusi dalam kelompoknya dalam upaya menyelesaikan masalah. Kesibukan siswa tersebut terjadi karena dalam pembelajaran berbasis masalah, pembelajaran tidak saja menekankan pada pengetahuan tetapi juga keterampilan yang diperlukan dalam belajar seperti pemecahan masalah, pemerolehan pengetahuan dan bekerja sama. Hal ini merupakan salah satu karakteristik pembelajaran berbasis masalah yaitu pembelajaran terpusat pada siswa, karena dalam pembelajaran berbasis masalah siswa dituntut berusaha dengan bersungguh-sungguh mencari penyelesaian masalah, mengidentifikasi apa yang dipelajari dan bagaimana cara terbaik untuk menyelesaikan masalah. Siswa perlu mengetahui bagaimana mengidentifikasi informasi yang penting yang perlu mereka pelajari, dimana memperoleh informasi dan bagaimana menggunakan informasi tersebut untuk menyelesaikan masalah.

Aspek penunjang lain dalam pembelajaran berbasis masalah adalah siswa belajar dalam kelompok kecil. Selain itu, dalam pembelajaran berbasis masalah siswa diberi keleluasaan untuk berinteraksi dengan temannya ataupun guru, saling berbagi, mengajukan pendapat atau ide sehingga konsep-konsep yang diperoleh digali secara mendalam dan bermakna. Melalui interaksi antara siswa, diharapkan terjadi pertukaran pengalaman belajar berbeda sehingga aksi mental dapat terus berlanjut sesuai dengan yang diharapkan. Sementara itu teknik scaffolding dapat digunakan selain untuk mengarahkan proses berpikir, juga untuk memberikan tantangan lanjutan sehingga aksi mental yang diharapkan dapat terjadi dengan baik.

Dengan adanya kerjasama yang berkesinambungan diharapkan dapat memperpendek jarak perbedaan kemampuan actual siswa. Hal ini sesuai dengan pendapat Schaps, Lewis\&Watson (Mikrayanti, Baeti, \& Wirahmat, 2018) menyatakan bahwa belajar kelompok menumbuhkan rasa sebagai bagian dari kelompok (sense of classroom community) dan memberi kontribusi positif kepada hasil belajar siswa. Hal ini disebabkan oleh motivasi belajar yang meningkat dan berkurangnya kecemasan siswa. Situasi inilah yang tampaknya 
menjadikan siswa pada kelas eksperimen terlatih/terbiasa. Ini merupakan faktor pendorong terjadinya aktivitas mental bersifat konstruktif dalam pembentukan obyek-obyek mental baru. Salah satu landasan yang dapat digunakan untuk mencapai tujuan tersebut antara lain adalah teori Zona of Proximal Development (ZPD) dari Vygotsky. Menurut Vygotsky belajar dapat membangkitkan berbagai proses mental tersimpan yang hanya bisa dioperasikan ketika seseorang berinteraksi dengan sesama temannya. Vygotsky yakin bahwa fungsi mental yang lebih tinggi pada umumnya muncul dalam diskusi dan kerjasama antara individu sebelum fungsi mental yang lebih tinggi terserap ke dalam individu tersebut.

Hal ini sangat berbeda dengan pembelajaran konvensional, setiap siswa bekerja secara individu sehingga menimbulkan adanya rasa persaingan di antara mereka. Sebaliknya pada pembelajaran berbasis masalah, muncul rasa tanggung jawab kepada kelompok, akibatnya setiap individu ingin membantu anggota kelompok lainnya dan setiap anggota memberi kontribusi kepada pencapaian tujuan kelompok. Kemampuan interpersonal turut berkembang karena dalam kelompok terlibat aspek komunikasi, kepemimpinan, pengambilan keputusan dan refleksi tentang kemajuan yang berhasil dicapai kelompok.

\section{KESIMPULAN}

Berdasarkan hasil analisis, hasil penelitian dan pembahasan diperoleh kesimpulan bahwa model pembelajaran berbasis masalah berpengaruh terhadap kemampuan komunikasi matematis antara siswa yang mendapat pembelajaran berbasis masalah dan siswa mendapat pembelajaran konvensional pada siswa Kelas XI IPA salah satu SMAN di Kabupaten Bima.

\section{REKOMENDASI}

Berdasarkan hasil penelitian, pembahasan dan kesimpulan dapat dikemukakan rekomendasi agar pembelajaran berbasis masalah dapat digunakan untuk meningkatkan kemampuan komunikasi matematis pada siswa di sekolah dan diharapkan pembelajaran berbasis masalah terus dikembangkan di lapangan secara meluas.

\section{UCAPAN TERIMAKASIH}

Ucapan terimakasih saya sampaikan pada Kepala SMA tempat penelitian dan ibu guru matematika serta teman-teman yang telah banyak memberikan masukan dalam pengembangandan penyelesaian penelitian ini. 


\section{REFERENSI}

MIKRAYANTI, M., BAETI, N., \& WIRAHMAT, I. (2018). MENINGKATKAN KEMAMPUAN KOMUNIKASI MATEMATIS MELALUI PEMBELAJARAN BERBASIS MASALAH. SUPERMAT (Jurnal Pendidikan Matematika), 2(1), 1827.

Mutmainah, M., Dusalan, D., \& Muchlis, M. (2018). PENGARUH PEMBELAJARAN PROBLEM BASED LEARNING TERHADAP KREATIVITAS MATEMATIKA SISWA PADA KELAS VIII UNGGULAN MTsN 1 MAKASSAR. SUPERMAT (Jurnal Pendidikan Matematika), 2(2), 18-28.

Nursakirah, N., Mikrayanti, M., \& Sowanto, S. (2020). PENGARUH MODEL PEMBELAJARAN TALKING STICK MENGGUNAKAN MEDIA TONGKAT TERHADAP HASIL BELAJAR MATEMATIKA SISWA SMA. SUPERMAT (Jurnal Pendidikan Matematika), 4(2), 1-11.

Sabandar, J. (2005). Pertanyaan Tantangan dalam Memunculkan Berpikir Kritis dan Kreatif dalam Pembelajaran Matematika. Makalah Disajikan dalam Seminar Nasional, FPMIPA UPI, 20 Oktober.

Shadiq, F. (2004). Pemecahan Masalah, Penalaran dan Komunikasi. Yogyakarta: PPPG Matematika.

Suherman, E. (2003). Evaluasi Pembelajaran Matematika untuk Calon Guru dan Mahasiswa Calon Guru Matematika. Bandung: Jurusan Pendidikan Matematika FPMIPA UPI.

Suhitno.(2003). Model Pembelajaran Matematika. Makalah Disampaikan pada Workshop Guru Bidang Studi Matematika Tanggal 27 Juli s.d 1 Agustus 2003 di PPPG Matematika Semarang. Semarang: Departemen Pendidikan Nasional Direktorat Jenderal Pendidikan Dasar dan Menengah Pusat Pengembangan Penataran Guru Matematika Semarang. 
Yurniwati. (2009).Meningkatkan Kemampuan Pemecahan Masalah dan Koneksi Matematis dengan Computer-Based Problem Solving pada Siswa SMP. Bandung : Prosiding Seminar Nasional Matematika dan Pendidikan Matematika 2009. 